\title{
Human Serum Proteins Recognized by CA215 and Cancerous Immunoglobulins and Implications in Cancer Immunology
}

\author{
Gregory Lee ${ }^{1,2}$, Suefay Liu ${ }^{1} \&$ Cheng-Yuan Huang ${ }^{1}$ \\ ${ }^{1}$ UBC Center for Reproductive Health, University of British Columbia, Vancouver, Canada \\ ${ }^{2}$ Department of Pathology, Shantou University Medical College, Shantou, China \\ Correspondence: Gregory Lee, UBC Center for Reproductive Health, University of British Columbia, \\ Vancouver, B.C., V6P 6R9, Canada. Tel: 1-604-325-4602. E-mail: cyglee@yahoo.com
}

\author{
Received: October 6, 2014 Accepted: October 29, 2014 Online Published: October 31, 2014 \\ doi:10.5539/cco.v3n2p51 URL: http://dx.doi.org/10.5539/cco.v3n2p51
}

\begin{abstract}
In 1987, a monoclonal antibody, RP215, was generated against the OC-3-VGH cancer cell line and shown to react with a carbohydrate-associated epitope located mainly on the heavy chains of immunoglobulins, designated as CA215, which are expressed on the surface of almost all cancer cells and not on normal immune cells. CA215 and cancerous immunoglobulins were affinity-isolated from the shed culture media of the same ovarian cancer cell line by using RP215-linked and anti-human immunoglobulin G-linked affinity chromatography, respectively. They were then immobilized separately as general ligands to isolate any protein components from pooled human sera which demonstrated affinity to CA215 and/or cancerous immunoglobulin $G$. The affinity-isolated components were then subjected to molecular analysis by liquid chromatography-tandem mass spectrometry (LC-MS/MS). Among the detected protein components, more than $72 \%$ were found to be commonly recognized by both CA2 15 and cancerous immunoglobulins. Some have previously been identified as endogenous proteins or fragments in human serum. They are considered generally, as cancer biomarkers, according to their pro-cancer (e.g. C4b binding protein $\alpha$ chain, complement $\mathrm{C} 3$, complement factor $\mathrm{H}$, serotransferrin, and vironectin), anti-cancer (e.g. $35 \mathrm{kDa}$ inter- $\alpha$-trypsin inhibition heavy chain 4 , anastellin, apolipoprotein A-1, fibrinogen $\beta$ chain, and, keratin type I cytoskeletal 9), or autoimmune (specific immunoglobulin G) properties, respectively. Therefore, besides serving a role for the growth/proliferation of cancer cells, cancerous immunoglobulins can also interact directly or indirectly with many other serum protein components or fragments for unspecified reasons and unknown mechanisms of action.
\end{abstract}

Keywords: CA215, cancer immunuology, cancerous immunoglobulins, RP215, serum proteins

\section{Introduction}

Expressions of immunoglobulins or immunoglobulin-like proteins among cancer cells have been known for decades (Babbage, Ottensmeier, Blaydes, Stevenson, \& Sahota, 2006; Chen \& Gu, 2007; D. Hu et al., 2011; F. Hu et al., 2012; J. Huang et al., 2008; J. Huang, Zhang, Ma, Zhang, \& Qiu, 2009; Kimoto, 1998; Lee \& Ge, 2009; M. Li, Tang, \& Deng, 2001; M. Li et al., 2004; Qiu et al., 2003; Yoshimi, Woo, Son, Baudry, \& Thompson, 2002; Zhang et al., 2012; H. Zheng, Li, Liu, et al., 2007; H. Zheng, Li, Ren, et al., 2007; J. Zheng et al., 2009; Zhu et al., 2008). However, little is known about their mechanisms of action in cancer immunology (Kimoto, 1998). Early experimental evidence seemed to suggest that they may play essential roles for the growth/proliferation of cancer cells in vitro or in vivo (M. Li et al., 2004; M. Li et al., 2012; Qiu et al., 2003). Recently, efforts have been made in our laboratory to identify these "antigens" in the human circulation which can be recognized by cancerous immunoglobulins (Lee, Huang, Liu, \& Zhang, 2013; Lee \& Liu, 2013; Lee, Huang, Tang, \& Zhang, 2014). The molecular nature of these antigens may be relevant to the growth/proliferation, as well as the immune protection of cancer cells in the natural human environment (Lee et al., 2013; Lee, Huang, Tang, et al., 2014).

A major breakthrough came in 1987, when a monoclonal antibody designated as RP215 was generated against the OC-3-VGH ovarian cancer cell line and shown to react specifically with a carbohydrate-associated epitope located mainly at the heavy chains of immunoglobulins expressed on the surface of almost all cancer cells, but not found on normal immune cells (Lee et al., 1992; Lee, Wu, Li, Ting, \& Chien, 2006). These immunoglobulin-related glycoproteins expressed by cancer cells with the RP215-specific "sugar" epitope are designated, in general, as CA215 (Lee, 2009; Lee, Ge, et al., 2009; Lee, Zhu, Ge, \& Potzold, 2012). Functional 
biological studies revealed that RP215 acts similarly to anti-cancerous immunoglobulins in inducing apoptosis and complement-dependent cytotoxicity (CDC) reactions to cultured cancer cells, as well as inhibiting tumor growth in nude mouse animal models (Lee, Chu, \& Ting, 2009; Lee \& Ge, 2010; Lee, Cheung, Ge, et al., 2012; Lee \& Ge, 2012; Lee, Zhu, \& Ge, 2012; Lee, Zhu, Ge, Cheung, et al., 2012; Lee, Zhu, Ge, \& Potzold, 2012). Furthermore, through gene regulation studies, it was generally concluded that the effects of RP215 on the regulations of related genes are highly correlated with those of antibodies against cancerous immunoglobulins or human immunoglobulin G (IgG) (Lee, Huang, Zhang, \& Tang, 2014; Tang, Zhang, \& Lee, 2013).

In this study, experiments were designed to isolate potential serum "antigens" which can be recognized by cancerous immunoglobulins from the human circulation (Lee, Huang, Tang, et al., 2014). Following affinity-isolation of CA215 and/or cancerous immunoglobulins from shed media of cultured cancer cells, CA215 and/or cancerous immunoglobulins were used as general affinity ligands to capture any serum protein components for further molecular analysis by liquid chromatography-tandem mass spectrometry (LC-MS/MS). Preliminary results are presented in this study in an attempt to explore the potential roles of immunoglobulins expressed by cancer cells.

\section{Materials and Method}

\subsection{Chemicals and Reagents}

All chemicals and reagents used in this study were obtained from Sigma Chemical Co (St. Louis, MO) unless otherwise mentioned.

\subsection{Cancer Cell Lines and Monoclonal Antibodies}

OC-3-VGH is an ovarian cancer cell line established in 1986 by the Department of Obstetrics and Gynecology at the Veterans General Hospital in Taipei, Taiwan (Chao, Ng, \& Chang, 1987). It is a cell line of ovarian serous origin and can be maintained in RPMI 1640 medium containing $10 \%$ bovine calf serum in a $5 \% \mathrm{CO}_{2}$ incubator at $37{ }^{\circ} \mathrm{C}$. This cancer cell line has been used to generate monoclonal antibodies for the development of antibody-based anti-cancer drugs during the last three decades. RP215 is one of these monoclonal antibodies generated against the OC-3-VGH ovarian cancer cell line and has been characterized extensively (Lee et al., 1992).

\subsection{Isolation of CA215, Cancerous Immunoglobulins, and Specific Human Serum Protein Components by Affinity Chromatography}

CA215 is a group of cancer cell-expressed glycoproteins, each of which contains the RP215-specific "sugar" epitope. Purified RP215 monoclonal antibody was employed as an affinity ligand to isolate CA215 from the shed medium of cultured OC-3-VGH ovarian cancer cells as described previously (Lee et al., 2006; Lee, Laflamme, Chien, \& Ting, 2008). Following adsorption and extensive buffer wash, the CA215 bound on the affinity gel was eluted from the affinity column with $5 \mathrm{mM}$ citric acid, followed by neutralization, dialysis, and concentration (Lee et al., 2006; Lee et al., 2008). Similarly, cancerous IgG (cIgG) was purified from shed media of culture cancer cells by affinity chromatography with goat anti-human IgG as the affinity ligand by using protocols similar to those for CA215. Any potential serum "antigens" which have affinity to CA215 or cancerous immunoglobulins can also be affinity-isolated with respective affinity columns from pooled human serum specimens. By employing the same affinity isolation procedures, specific serum proteins were obtained and designated as CA215-S+ and cIgG-S + , respectively, depending on the affinity ligand used for purification. Following purification, CA215-S+ and cIgG-S+ were concentrated and dialyzed, separately, with $5 \mathrm{mM}$ ammonium bicarbonate followed by freeze-drying. The purified serum "proteins" were then subjected to LC-MS/MS analysis through a contract service from the University of Victoria Genomic BC Proteomics Centre (Victoria, BC, Canada; project \#: REC-1434) to be described in a later section.

\subsection{Brief Description of LC-MS/MS Analysis}

The following steps were employed to perform molecular analysis of isolated serum antigens (CA215-S+ or cIgG-S + ), which can be recognized by CA 215 or cIgG, respectively.

\subsubsection{Trypsin Digestion}

About $200 \mu \mathrm{g}$ of CA215-S+ or cIgG-S + was rehydrated with $200 \mu \mathrm{L}$ of $25 \mathrm{mM}$ ammonium bicarbonate prior to reduction with $10 \mu \mathrm{L}$ of $200 \mathrm{mM}$ dithiothreitol (DTT) for 30 minutes at $37{ }^{\circ} \mathrm{C}$. Cysteine sulfhydryl groups were alkylated with $20 \mu \mathrm{L}$ of $200 \mathrm{mM}$ iodoacetamide for 30 minutes at $37^{\circ} \mathrm{C}$ in darkness. Following addition of $20 \mu \mathrm{L}$ of $200 \mathrm{mM}$ DTT to quench alkylation, $10 \mu \mathrm{g}$ trypsin (Promega) was added to each sample for 16 hours at $37^{\circ} \mathrm{C}$. A Waters Oasis hydrophilic-lypophilic balanced column $(1 \mathrm{~mL}, 10 \mathrm{mg})$ was equilibrated with $2 \mathrm{~mL}$ acetonitrile 
(CAN) and then $2 \mathrm{~mL} 0.6 \%$ acetic acid. The supernatant was applied to the column by $2 \mathrm{~mL} 0.6 \%$ acetic acid and peptides were eluted with $700 \mu \mathrm{L} 80 \% \mathrm{CAN} / 0.6 \%$ acetic acid. The samples were concentrated via speed vac, acidified, and desalted with $\mathrm{C} 19$ Stage Tips prior to LC-MS/MS analysis.

\subsubsection{LC-MS/MS Analysis}

The peptide mixtures were separated by online reverse reverse-phase chromatography with a Thermo Scientific Easy-Inc 1000 system at a flow rate of $300 \mathrm{~nL} / \mathrm{min}$. The chromatography system was coupled online with an Orbitrap Fusion Tribid mass spectrometer (Thermo Scientific, San Jose, CA). The standard operation manual was used for MS analysis of the peptide mixture in the samples.

Raw files were created by X Caliber 3.0.63 (Thermo Scientific) software and analyzed with Proteome Discoverer 1.4.1.14 software suite (Thermo Scientific).

\subsection{Apoptosis Experiments}

Previous studies have indicated that through binding to the RP215-specific epitope in CA215 on the surface of cultured cancer cells, apoptosis was induced as judged by using the TUNEL assay method (Chen \& Gu, 2007; Lee et al., 2010; Lee \& Ge, 2010; Lee, Cheung, Ge, et al., 2012; M. Li et al., 2012; Qiu et al., 2003; H. Zheng, Li, Liu, et al., 2007). By using similar assay protocols, apoptosis experiments were performed to see if the affinity-isolated CA215-S+ and cIgG-S+-related human serum protein components can induce apoptosis to cultured cancer cells. Detailed experiment procedures have been described previously (Lee, Cheung, Ge, et al., 2012).

\section{Results}

\subsection{Biochemical and Immunological Characterizations of CA215-S+ and $\operatorname{cIg} G-S_{+}$}

CA215 and cIgG were isolated from shed medium of cultured OC-3-VGH ovarian cancer cells by affinity chromatography with RP215 and goat anti-human IgG as separate general ligands. Purified CA215 was subjected to matrix-assisted laser desorption/ionization time-of-flight mass spectrometry (MALDI-TOF MS) analysis and details of such analysis have been reported previously (Lee, Zhu, Ge, \& Potzold, 2012). It was generally concluded that RP215-specific CA215 was found to be cancerous glycoproteins which consist mainly of immunoglobulin heavy chains and other immunoglobulin superfamily proteins ( $\geq 60 \%$ ) (Lee et al., 2006; Lee et al., 2008; Lee \& Azadi, 2012; Lee, Cheung, Li, Ge, \& Chow, 2012). Therefore, in this study, both CA215 and cancerous immunoglobulins were affinity purified and served, respectively, as general affinity ligands to capture any serum protein components in pooled human serum samples. The affinity-isolated serum protein components, designated separately as CA215-S+ and cIgG-S+, were then subjected to LC-MS/MS analysis. The identified human serum proteins or fragments were listed and classified through such analysis. Details are presented in the Appendix of this publication. More than fifty serum proteins or fragments were detected in either of the CA215-S+ or cIgG-S+ protein fractions. Among the detected and identified protein components, as many as $72 \%$ were found to be identical between those isolated by CA215 and cIgG affinity columns.

Among the serum proteins or fragments detected by LC-MS/MS, more than half were found to be relevant to the growth/proliferation or inhibition of cancer cells in vitro or in vivo, as demonstrated by other researchers (M. Li et al., 2004; M. Li et al., 2012; Qiu et al., 2003). However, some of the detected serum proteins were found to have no known functional roles to cancer cells in humans. The detected proteins or components are listed in Table 1 according to their known functional properties as "pro-cancer," or "anti-cancer." The original data analyzed by protein software anlaysis are presented in the Appendix file. Details of the pro- and anti-cancer serum protein components will be discussed in later sections. 
Table 1. Functional classifications of the detected human serum proteins and/or fragments as recognized by both CA215 and cIgG through the LC-MS/MS method

\begin{tabular}{|c|c|c|c|}
\hline $\begin{array}{l}\text { Functional } \\
\text { property }\end{array}$ & Protein & $\begin{array}{l}\text { Molecular weight } \\
\text { (kDa) }\end{array}$ & Reference \\
\hline \multirow{9}{*}{ Pro-cancer } & C4b-binding protein $\alpha$ chain & 67 & $\begin{array}{l}\text { (Holmberg, Blom, \& Meri, 2001; } \\
\text { Markiewski \& Lambris, 2009) }\end{array}$ \\
\hline & Complement $\mathrm{C} 3$ & 187 & $\begin{array}{l}\text { (Kitano \& Kitamura, 1993; } \\
\text { Markiewski et al., 2008; Rutkowski, } \\
\text { Sughrue, Kane, Mills, \& Parsa, 2010) }\end{array}$ \\
\hline & Complement factor $\mathrm{H}$ & 139 & $\begin{array}{l}\text { (Ajona et al., 2004; Ajona, Hsu, } \\
\text { Corrales, Montuenga, \& Pio, 2007; } \\
\text { Holmberg et al., 2001; Junnikkala et } \\
\text { al., 2002; Wilczek et al., 2008) }\end{array}$ \\
\hline & Serotransferrin & 77 & $\begin{array}{l}\text { (Macuks, Baidekalna, Gritcina, } \\
\text { Avdejeva, \& Donina, 2010; Rossi \& } \\
\text { Zetter, 1992; Schaeffer, Boissier, Py, } \\
\text { Cohen, \& Zakin, 1989; I S } \\
\text { Trowbridge \& F Lopez, 1982) }\end{array}$ \\
\hline & Vitronectin & 54 & $\begin{array}{l}\text { (Felding-Habermann \& Cheresh, } \\
\text { 1993; Hurt et al., 2010; Kenny, Kaur, } \\
\text { Coussens, \& Lengyel, 2008; } \\
\text { Pirazzoli, Ferraris, \& Sidenius, 2013) }\end{array}$ \\
\hline & Others: $\alpha 2$ macroglobulin & 163 & $\begin{array}{l}\text { (Misra \& Pizzo, 2012; Smorenburg et } \\
\text { al., 1996) }\end{array}$ \\
\hline & CD5 antigen-like protein & 38 & (Y. Li et al., 2011) \\
\hline & Isoform 2 of $\alpha$-1-antitrypsin & 40 & (López-Árias et al., 2012) \\
\hline & Hemopexin & 52 & (Nakajima et al., 2000) \\
\hline \multirow{6}{*}{ Anti-cancer } & $\begin{array}{l}35 \mathrm{kDa} \text { inter- } \alpha \text {-trypsin inhibitor heavy } \\
\text { chain } 4\end{array}$ & 104 & $\begin{array}{l}\text { (Hamm et al., 2008; M. Huang, } \\
\text { Wang, Zhang, Li, \& Li, 2013) }\end{array}$ \\
\hline & Anastellin & 256 & $\begin{array}{l}\text { Neskey, Ambesi, Pumiglia, \& } \\
\text { McKeown-Longo, 2008; Pasqualini, } \\
\text { Bourdoulous, Koivunen, Woods, \& } \\
\text { Ruoslahti, 1996; M. Yi \& Ruoslahti, } \\
\text { 2001) }\end{array}$ \\
\hline & Apolipoprotein A-1 & 31 & $\begin{array}{l}\text { (Macuks et al., 2010; } \\
\text { Zamanian-Daryoush et al., 2013) }\end{array}$ \\
\hline & Fibrinogen $\beta$ chain & 56 & (Krajewska et al., 2010) \\
\hline & Keratin type I cytoskeletal 9 & 62 & (W. Yi et al., 2013) \\
\hline & $\begin{array}{l}\text { Others: Complement component } \mathrm{C} 4 \mathrm{~b} \\
\text { (Childo blood group) }\end{array}$ & 193 & $\begin{array}{l}\text { (Markiewski \& Lambris, 2009; } \\
\text { Rutkowski et al., 2010) }\end{array}$ \\
\hline
\end{tabular}

3.2 Binding Assays to Reveal Specific Binding Between Affinity-Purified CA215-S+ (or cIgG-S+) and CA215 (or clgG)

Prior to LC-MS/MS analysis of the affinity-purified CA215-S+ and cIgG-S+, the relative binding affinity and specificity of these human serum components (in CA215-S+ or cIgG-S+) recognized by CA215 or cIgG were 
demonstrated by ELISA. Briefly, CA215-S+ and cIgG-S+ were coated separately, on microwells according to standard procedures (Lee, Huang, Tang, et al., 2014). CA215 and cIgG were biotinylated and used as the primary antibody for $60 \mathrm{~min}$ incubation at $37^{\circ} \mathrm{C}$. This was followed by washes, and addition of alkaline phosphatase (ALP)-labeled avidin for $60 \mathrm{~min}$ incubation at $37^{\circ} \mathrm{C}$. The dose-dependent bindings between biotinylated CA215 (or $\mathrm{cIgG}$ ) and the corresponding $\mathrm{CA} 215-\mathrm{S}+($ or $\mathrm{cIgG}-\mathrm{S}+$ ) were determined by EIA reader and expressed in histograms (Figure 1).

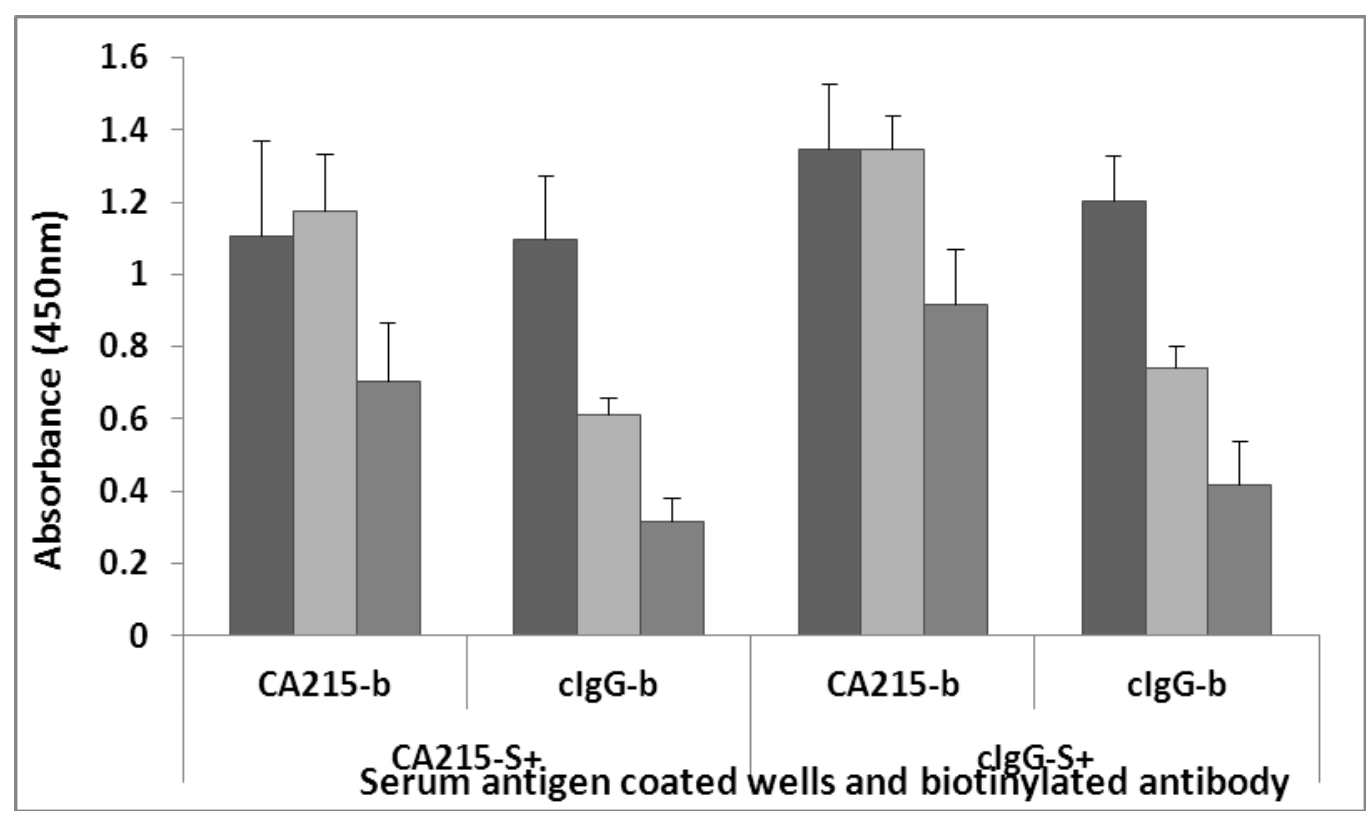

Figure 1. Enzyme immunobinding assay to reveal specific binding between well-coated purified serum antigens of CA2 15 or $\operatorname{cIgG}$ and biotinylated CA2 15 or $\operatorname{cIgG}$

Biotinylated CA215 (CA215-b) and cIgG (cIgG-b) of different dilutions ( $\square 2 \mu \mathrm{g} / \mathrm{mL}, \quad \square 1 \mu \mathrm{g} / \mathrm{mL}$, and $0.5 \mu \mathrm{g} / \mathrm{mL}$ ) were added to microwells coated with eluted serum antigen from CA215 (CA215-S+) and cIgG $\left(\right.$ cIgG-S+)) for $3 \mathrm{hr}$ incubation at $37^{\circ} \mathrm{C}$. ALP-labeled avidin was added for additional 60 min incubation followed by color substrate development at $405 \mathrm{~nm}$. The data are presented as duplicates following subtraction of corresponding negative control which served as the blank. Wells coated with unrelated proteins served as the negative control. Dose-dependent bindings were statistically significant. Modified from (Lee, Huang, Tang, et al., 2014) with permission.

\subsection{Analysis of Serum Protein Components Recognized by Both CA215 and cIgG Through LC-MS/MS}

Previously, it has been hypothesized the cancerous immunoglobulins serve duals roles within cancer cells. Firstly, the interacting human serum proteins may be recognized for the growth/proliferation of cancer cells. Secondly, some of the human serum proteins may be cytotoxic to cancer cells and be neutralized by interactions with cancerous immunoglobulins or CA215 for immune protection of cancer cells.

Many serum proteins were found to be involved in the interaction with CA215 and/or cIgG expressed by cancer cells. Generally speaking, as many as $72 \%$ of the detected serum proteins were found to be commonly recognized by both CA215 and cIgG when either one was used as general ligands for affinity purification of human serum proteins. Following detailed protein analysis of LC-MS/MS data, they were classified and listed according to their nature as pro-and anti-cancer properties (see Table 1).

The molecular and biological characteristics of most of these naturally detected pro-cancer and anti-cancer components have been studied previously by others (refer to references in Table 1). However, some of the detected serum protein components were found to have no known functional roles among cancer cells. Some were found to be human immunoglobulins which exhibited affinity to CA215 or cancerous immunoglobulins. They can only be classified as auto-antibodies within the human circulation. It remains to be seen whether there are any functional roles of these auto-antibodies in cancer cells.

Judging from these considerations, the detected serum components were classified into three categories: i) 
pro-cancer, ii) anti-cancer components, and iii) components with autoimmune or unknown functions. The first two classifications are presented in Table 1 for comparative purposes. Among the pro-cancer serum components detected by CA215 or cIgG, the most notable ones included: a) C4b-binding protein, b) complement C3, c) complement factor $\mathrm{H}$, d) serotransferrin, and e) vitronectin. Among the anti-cancer serum components detected by CA2 15 or $\mathrm{cIgG}$, the most notable ones included: a) $35 \mathrm{kDa}$ inter- $\alpha$-trypsin inhibitor heavy chain 4 , b) anastellin, c) apolipoprotein A1, d) fibrinogen $\beta$ chain, and e) keratin type I cytoskeletal 9. Brief descriptions of these pro-cancer and anti-cancer serum components detected by CA215 or cIgG and their cancer-associated effects have been reported previously and will be described in the discussion.

\subsection{Comparative Results of Induced Apoptosis}

As shown in Figure 2A, the serum protein components bound by CA215, CA215-S+ did not exhibit any significant increase in induced apoptosis of cultured OC-3-VGH ovarian cancer cells. These results may be explained based on the fact that the serum protein components bound by CA2 15 are a mixture of minor proteins or components which have either pro- or anti-cancer effects. The respective effects of the pro- and anti-cancer serum components may result in no apparent overall effect on induced apoptosis to the cancer cells. By comparison, RP215 or anti-human IgG were shown to induce significant induced apoptosis to cultured cancer cells as demonstrated in Figure 2B under the same TUNEL assay conditions (Lee, Cheung, Ge, et al., 2012).

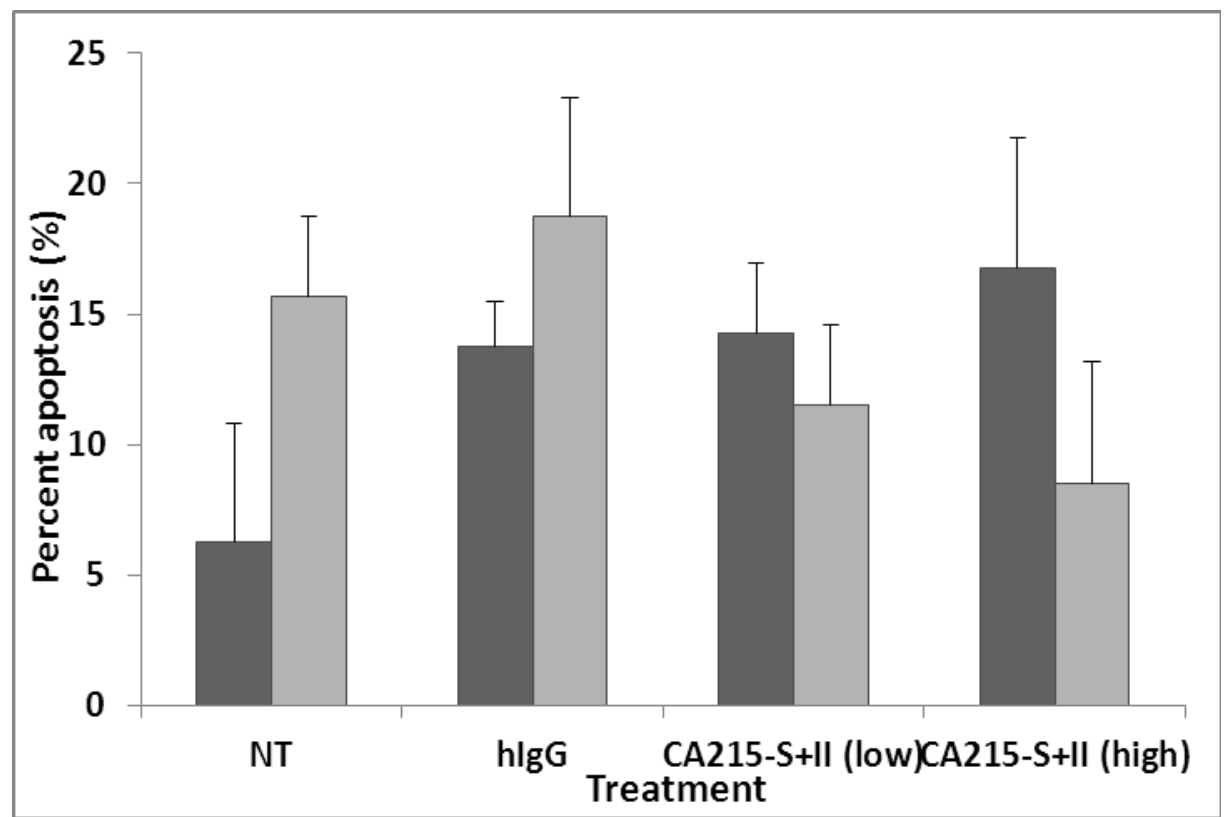

Figure 2. (A) Percent apoptosis of OC-3-VGH cells following $24 \mathrm{hrs}$ and $48 \mathrm{hrs}$ treatment with eluted serum antigens from CA215

OC-3-VGH cells were incubated for $24 \mathrm{hrs}(\square)$ and $48 \mathrm{hrs}(\square)$ with low $(1 \mu \mathrm{g} / \mathrm{mL})$ and high doses $(5 \mu \mathrm{g} / \mathrm{mL})$ of eluted serum purified by CA215 affinity column twice (CA215-S+II). No treatment (NT) and human IgG (hIgG) were used as negative controls. Compared to the negative control, no treatment or hIgG, the results were not statistically significant $(\mathrm{P}>0.05)$. 


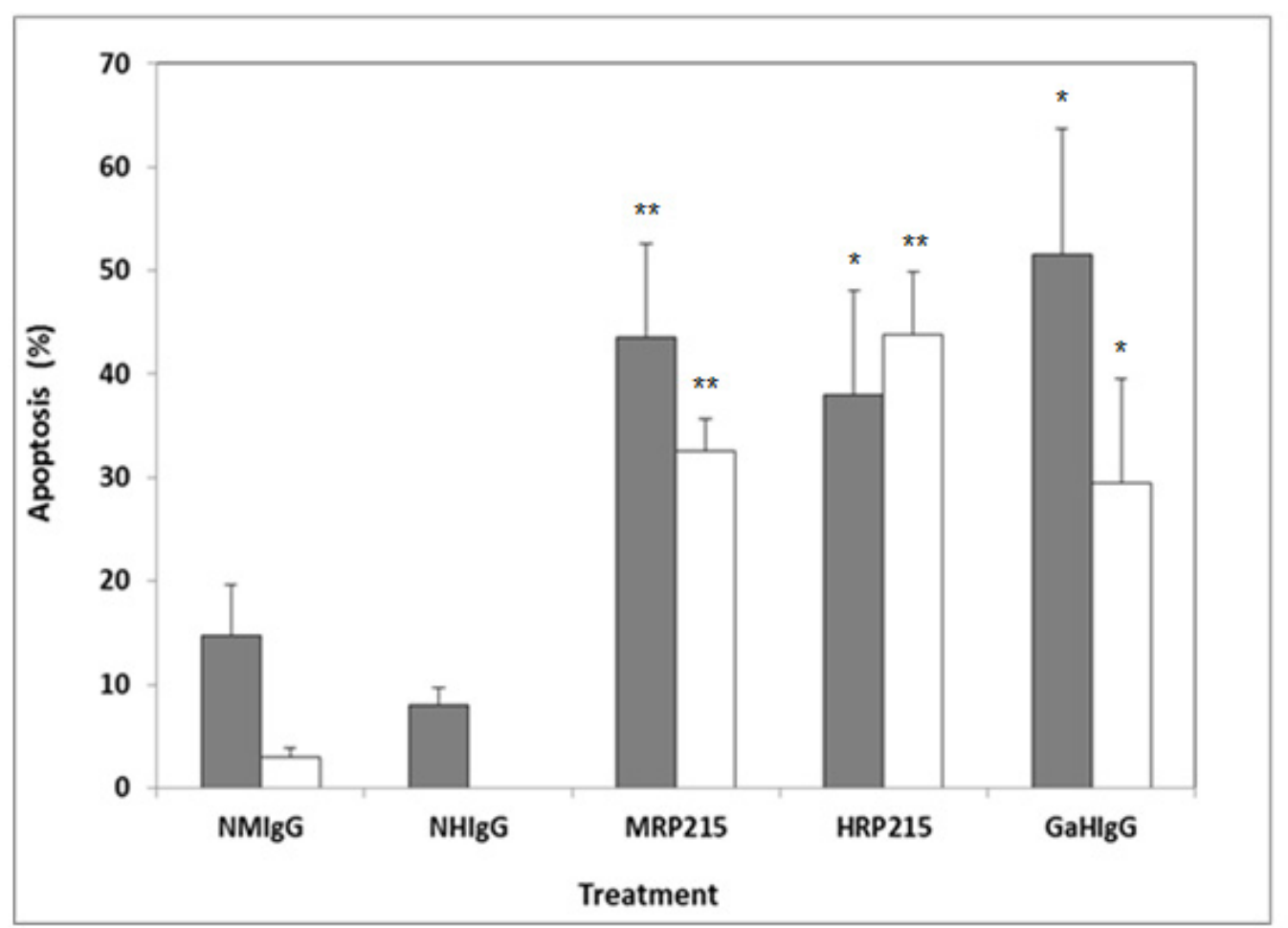

Figure 2. (B) Percent apoptosis of OC-3-VGH cells following $24 \mathrm{hrs}$ treatment with $1 \mu \mathrm{g} / \mathrm{mL}$ and $10 \mu \mathrm{g} / \mathrm{mL}$ of murine and humanized RP215 and goat anti-human IgG

OC-3-VGH cells were incubated for $24 \mathrm{hrs}$ of $1 \mu \mathrm{g} / \mathrm{mL}$ ( $\square$ ) and $10 \mu \mathrm{g} / \mathrm{mL}$ ( $\square$ ) of murine and humanized RP215 (MRP215 and HRP215) and goat anti-human IgG (GaHIgG). Normal mouse IgG (NMIgG) and normal human IgG (NHIgG) were used as negative controls. Compared to the negative control, the results were statistically significant $(*: \mathrm{P}<0.01, * *: \mathrm{P}<0.001)$.

\section{Discussion}

Following two steps of affinity chromatography starting with shed culture media of ovarian cancer cells, CA215-S+ and cIgG-S+ were isolated from pooled human sera. These serum protein components were subjected to tryptic digestion and LC-MS/MS analysis. The detected serum protein components were classified mainly as pro-cancer and anti-cancer in nature. They are briefly described in the following, with emphasis on their proor anti-cancer properties reported in the previous sections:

\subsection{Pro-Cancer Serum Protein or Components}

\subsubsection{4b-Binding Protein $\alpha$ Chain}

C4b-binding protein is a soluble complement inhibitor which is composed of seven identical $\alpha$ chains and one unique $\beta$ chain. It inhibits complement activation by acting as a cofactor for factor I-mediated degradation of C3b and C4b (Markiewski \& Lambris, 2009). In SKOV-3 and CAOV-3 ovarian adenocarcinoma cell lines, it has been found that $\mathrm{C} 4 \mathrm{~b}$-binding protein binds to these cancer cells via C4-binding protein's $\alpha$ chain domain and is capable of inhibiting the complement classical pathway by factor I-mediated inactivation of $\mathrm{C} 4 \mathrm{~b}$ (Holmberg et al., 2001). Therefore, binding of C4b-binding protein by cancer cells helps protect cancer cells by inhibiting complement activation (Holmberg et al., 2001).

\subsubsection{Complement $\mathrm{C} 3$}

Complement $\mathrm{C} 3$ is a central protein in the complement cascade and its cleavage products, $\mathrm{C} 3 \mathrm{a}$ and $\mathrm{C} 3 \mathrm{~b}$, have been found to be deposited in engrafted tumors in mice models (Markiewski et al., 2008). Mice deficient in C3 also exhibited significantly decreased tumor proliferation compared to wild-type mice (Markiewski et al., 2008). In another study, a cleavage product of complement $\mathrm{C} 3, \mathrm{C} 3 \mathrm{a}$ was found to demonstrate proliferative activities and increase activation of proteins whose overexpression has been strongly associated with neoplasia (Rutkowski et al., 2010; Vivanco \& Sawyers, 2002). Other tumorigenic effects of C3 include production of 
vascular endothelial growth factor (VEGF), extracellular matrix reorganization, disintegration for tumor angiogenesis and invasion/migration (Rutkowski et al., 2010). In addition, some human gastric cancer-derived cell lines have been observed to synthesize C3 (Kitano \& Kitamura, 1993). Therefore, despite playing a key role in the complement cascade, $\mathrm{C} 3$ also promotes cancer development and progression.

\subsubsection{Complement Factor $\mathrm{H}$}

Complement factor $\mathrm{H}$ is a serum glycoprotein and key regulator of the alternative pathway of the complement system. Specifically, complement factor $\mathrm{H}$ protects host cells and tissues from complement activation by acting as a cofactor for serine protease factor I to induce cleavage and inactivation of $\mathrm{C} 3 \mathrm{~b}$ and $\mathrm{C} 4 \mathrm{~b}$, as well as to accelerate the degradation of C3 convertase (Jozsi \& Zipfel, 2008). Complement factor $\mathrm{H}$ has been found to be expressed and secreted by many primary tumors and cancer cell lines, including glioblastomas, myoblastomas, and carcinomas of the bladder, ovary, and lung (Ajona et al., 2007; Holmberg et al., 2001; Junnikkala et al., 2000; Junnikkala et al., 2002; Wilczek et al., 2008). In addition, it has been found that these cancer cells are resistant to complement-mediated cytolysis. Downregulation of complement factor $\mathrm{H}$ has been found to sensitize cancer cells to complement attack and reduce tumor growth, and therefore it has been hypothesized that complement factor $\mathrm{H}$ acts to protect cancer cells from complement activation (Ajona et al., 2004; Ajona et al., 2007; Junnikkala et al., 2000; Wilczek et al., 2008).

\subsubsection{Serotransferrin}

Serotransferrin (serum transferrin) is an iron binding transport protein within the human body. It transports iron from sites of iron absorption and heme degradation to sites of storage and utilization. Iron plays an integral role in various cellular functions, including in energy metabolism and cell growth, and it has long been known that serotransferrin is involved in stimulating cell proliferation (Ponka, 1999; Schaeffer et al., 1989). It has been demonstrated that many cancer cells, including those derived from the prostatic and lung carcinomas, express transferrin receptors which bind to serotransferrin and cause cancer cell proliferation (Laskey, Webb, Schulman, \& Ponka, 1988; Rossi \& Zetter, 1992; Vostrejs, Moran, \& Seligman, 1988). By blocking transferrin binding to the cancer cell surface, tumor growth can be inhibited in vitro (Laskey et al., 1988; I. S. Trowbridge \& F. Lopez, 1982). Therefore, serotransferrin is an important growth factor for cancer cell proliferation.

\subsubsection{Vitronectin}

Vitronectin is a glycoprotein found in the serum or extracellular matrix, and is produced primarily in the liver. It has been shown that vitronectin is an inducer of cancer stem cell differentiation in breast and prostatic carcinoma through interaction with the integrin family of proteins which are involved in adhesion, differentiation, survival, and growth (Felding-Habermann \& Cheresh, 1993; Hurt et al., 2010). In addition, interaction of the urokinase receptor and vitronectin has been found to induce cancer cell spreading, migration, and growth (Kenny et al., 2008; Pirazzoli et al., 2013).

\subsection{Anti-Cancer Serum Proteins or Components}

\subsection{1 $35 \mathrm{kDa}$ Inter- $\alpha$-Trypsin Inhibitor Heavy Chain 4}

Inter- $\alpha$-trypsin inhibitor heavy chain 4 is a fragment of the inter- $\alpha$-trypsin inhibitor heavy chain 4 , which is a type II acute phase protein secreted by the liver (Pineiro et al., 1999; Salier, Rouet, Raguenez, \& Daveau, 1996). It has plasma kallikrien sensitivity, and is $\mathrm{O}$ glycosylated and assumed to not undergo further cleavage or modification (Nishimura et al., 1995). One study has found that inter- $\alpha$-trypsin inhibitor heavy chain genes, including, inter- $\alpha$-trypsin inhibitor heavy chain 4 , are frequently downregulated in multiple solid tumors, thereby leading to initiation and progression of these tumors (Hamm et al., 2008). Furthermore, downregulation of the inter- $\alpha$-trypsin inhibitor heavy chain 4 by siRNA was found to increase cell proliferation and migration (M. Huang et al., 2013).

\subsubsection{Anastellin}

Anastellin is a fragment of the first type III module of fibronectin which binds to a variety of proteins, including integrins, proteoglycans, fibronectin, and fibrinogen (Ambesi \& McKeown-Longo, 2009; M. Yi \& Ruoslahti, 2001). Through binding to fibronectin, anastellin is capable of promoting changes in the organization and assembly of the fibronectin matrix (Neskey et al., 2008). Anastellin has been found to inhibit tumor growth and metastasis in vivo through its inhibitory effects on angiogenesis (Pasqualini et al., 1996; M. Yi \& Ruoslahti, 2001). Studies performed using human microvessel endothelial cells have shown that anastellin inhibits serum dependent cell growth by blocking progression of the cell cycle (Neskey et al., 2008). 


\subsubsection{Apolipoprotein A-1}

Apolipoprotein A-1 is a major protein component of high-density lipoprotein (HDL) in human plasma and has anti-inflammatory, as well as antioxidant capabilities (Zamanian-Daryoush et al., 2013). It is considered a cardioprotective protein and may have a role as a therapeutic agent for cardiovascular disease (Zamanian-Daryoush et al., 2013). Apolipoprotein A-1 has been shown to be a biomarker of ovarian cancer and in combination with CA215 increased the sensitivity for ovarian cancer detection (Macuks et al., 2010). In addition, apolipoprotein A-1 has been found to suppress tumor growth and metastasis in multiple animal tumor models, including the B16F10L murine malignant tumor model, in an indirect manner through modulation of the immune system (Zamanian-Daryoush et al., 2013). The net functional effects of apolipoprotein A-1 include a decrease in tumor growth, angiogenesis, metastasis, invasion, and myeloid derived suppressor cell recruitment, and an increase in anti-tumor macrophages and CD8+ T cells (Zamanian-Daryoush et al., 2013). Furthermore, mice lacking apolipoprotein A-1 were found to develop tumors quicker than mice expressing the gene (Zamanian-Daryoush et al., 2013).

\subsubsection{Fibrinogen $\beta$ Chain}

Fibrinogen $\beta$ chain is one of the three peptide chains $(\alpha, \beta$, and $\gamma)$ that compose fibrinogen, a protein involved in the formation of blood clots. In cancerous tissue, fibrinogen promotes tumor angiogenesis by supporting cell adhesion, migration, proliferation, and differentiation of activated endothelial cells (Zacharski, Memoli, \& Rousseau, 1986). In particular, it has been found that the first 20 amino acids of the $\mathrm{N}$ terminus of the fibrinogen beta chain ( $\beta 43-63$ ) significantly inhibit VEGF-activated adhesion of epithelial cells to the extracellular matrix (Krajewska et al., 2010). In addition, in mouse models, this peptide was found to inhibit tumor vascularization and increase tumor necrosis (Krajewska et al., 2010).

\subsubsection{Keratin Type I Cytoskeletal 9}

Keratin type I cytoskeletal 9 is a structural protein which makes up the intermediate filaments present in epidermal cells. In particular, keratin type I cytoskeletal 9 is an acidic keratin and mutations in its gene have been linked to epidermolytic plamoplantarkeratoderma (Reis et al., 1994). In a proteomic analysis of the breast cancer cell line, SKBR-3, keratin type I cytoskeletal 9 was identified in the tryptic digest of SKBR-3 cell extract (Wu, Hancock, Goodrich, \& Kunitake, 2003). In addition, keratin type I cytoskeletal 9 was found to be downregulated in drug resistant human breast cancer tissue, and therefore, keratin type I cytoskeletal 9 may be correlated with drug sensitivity of cancer tissues (W. Yi et al., 2013).

\subsection{Apoptosis Results}

CA215-S+ and cIgG-S+ affinity-purified from pooled human sera have been demonstrated by enzyme immunoassay (EIA) (Figure 1) to have significant dose-dependent binding activity to CA215 and cIgG. In spite of the binding of CA215 or cIgG on the cancer cell surface, these purified human serum protein components (1 $\mu \mathrm{g} / \mathrm{mL}$ ) were shown to have little effect on the induced apoptosis to cancer cells (Figure 2A). This result is in contrast to RP215 or anti-human IgG, both of which were shown to induce apoptosis of cancer cells under the same culture and assay conditions (Figure 2B). By comparison, surface-bound CA215 or clgG were targeted nonspecifically by binding with RP2 15 or anti-human IgG and apoptosis was readily induced to cultured cancer cells. In contrast, CA215-S + and clgG-S + may selectively target both minor anti-cancer and pro-cancer components recognized by CA2 15 or $\mathrm{cIgG}$ on the cancer cell surface. This could result in the absence of induced apoptosis caused by CA215-S + or cIgG-S + to cancer cells.

\subsection{Implications in Cancer Immunology}

The natures of interactions between CA215-S+ or cIgG-S+ and CA215 or cIgG are currently unknown. The traditional antigen-antibody reactions or other specific/non-specific bindings cannot be ruled out at this moment. This may require more detailed future investigations of each detected serum component which can be recognized by CA215 or cIgG. Based on the results of this molecular analysis, it can be hypothesized that immunoglobulins expressed on the cancer cell surface may serve as receptors to interact with human serum protein components which may have potential pro- and anti-cancer properties in the human circulation (Lee, 2012). The hypothesis of dual roles of cancerous immunoglobulins has been properly demonstrated through their interactions with both pro-cancer and anti-cancer human serum components in the present study. The observations from this study may also consistently explain the molecular mechanisms of action of the widespread expression of immunoglobulins by cancer cells or cancerous tissues (Chen \& Gu, 2007; Chen, Qiu, \& Gu, 2009; Chen et al., 2010; Qiu et al., 2003). RP215 monoclonal antibody also reacts with a specific "sugar" epitope of cancerous immunoglobulins to induce apoptosis and CDC to most cancer cells (Lee, Chu, et al., 2009; Lee \& Ge, 2010; Lee, Cheung, Ge, et al., 
2012; Lee \& Ge, 2012; Lee, Zhu, \& Ge, 2012; Lee, Zhu, Ge, Cheung, et al., 2012; Lee, Zhu, Ge, \& Potzold, 2012). Therefore, surface bound immunoglobulins on cancer cells, which play vital roles in cancer cell growth/proliferation and immune protection, may become a novel and unique target of RP215 for antibody-based anti-cancer therapy, provided that preclinical and clinical evaluations of the humanized forms of RP215 are successfully completed in the near future (Lee, Huang, \& Ge, 2014).

\section{Acknowledgments}

This research project was initiated in Fall 2013 with Professor Jiang Gu when Dr. Gregory Lee was a visiting professor at the Department of Pathology, Shantou University, Shantou, China. Professor Gu's helpful suggestions to this project are acknowledged. This research work was supported in parts by a travel grant from Shantou University and NRC-IRAP program (\#821-901) of Canada.

\section{References}

Ajona, D., Castano, Z., Garayoa, M., Zudaire, E., Pajares, M. J., Martinez, A., ... Pio, R. (2004). Expression of complement factor $\mathrm{H}$ by lung cancer cells: effects on the activation of the alternative pathway of complement. Cancer Research, 64(17), 6310-6318. http://dx.doi.org/10.1158/0008-5472.can-03-2328

Ajona, D., Hsu, Y. F., Corrales, L., Montuenga, L. M., \& Pio, R. (2007). Down-regulation of human complement factor $\mathrm{H}$ sensitizes non-small cell lung cancer cells to complement attack and reduces in vivo tumor growth. J Immunol, 178(9), 5991-5998. http://dx.doi.org/10.4049/jimmunol.178.9.5991

Ambesi, A., \& McKeown-Longo, P. J. (2009). Anastellin, the angiostatic fibronectin peptide, is a selective inhibitor of lysophospholipid signaling. Molecular Cancer Research, 7(2), 255-265. http://dx.doi.org/10.1158/1541-7786.mcr-08-0195

Babbage, G., Ottensmeier, C. H., Blaydes, J., Stevenson, F. K., \& Sahota, S. S. (2006). Immunoglobulin heavy chain locus events and expression of activation-induced cytidine deaminase in epithelial breast cancer cell linesCancer Research (Vol. 66, pp. 3996-4000). http://dx.doi.org/10.1158/0008-5472.can-05-3704

Chao, K. C., Ng, H. T., \& Chang, C. C. (1987). Characteristics of a newly established ovarian carcinoma cell line--OC-3-VGH. Zhonghua Yi Xue Za Zhi (Taipei), 39(3), 147-152.

Chen, Z., \& Gu, J. (2007). Immunoglobulin G expression in carcinomas and cancer cell lines. FASEB Journal, 21, 2931-2938. http://dx.doi.org/10.1096/fj.07-8073com

Chen, Z., Qiu, X., \& Gu, J. (2009). Immunoglobulin expression in non-lymphoid lineage and neoplastic cells. American Journal of Pathology, 174(4), 1139-1148. http://dx.doi.org/10.2353/ajpath.2009.080879

Chen, Z., Huang, X., Ye, J., Pan, P., Cao, Q., Yang, B., ... Gu, J. (2010). Immunoglobulin G is present in a wide variety of soft tissue tumors and correlates well with proliferation markers and tumor grades. Cancer, 116(8), 1953-1963. http://dx.doi.org/10.1002/cncr.24892

Felding-Habermann, B., \& Cheresh, D. A. (1993). Vitronectin and its receptors. Current Opinion in Cell Biology, 5(5), 864-868.

Hamm, A., Veeck, J., Bektas, N., Wild, P., Hartmann, A., Heindrichs, U., ... Dahl, E. (2008). Frequent expression loss of Inter-alpha-trypsin inhibitor heavy chain (ITIH) genes in multiple human solid tumors: A systematic expression analysis. BMC Cancer, 8(1), 25.

Holmberg, M. T., Blom, A. M., \& Meri, S. (2001). Regulation of complement classical pathway by association of C4b-binding protein to the surfaces of SK-OV-3 and CAOV-3 ovarian adenocarcinoma cells. The Journal of Immunology, 167(2), 935-939. http://dx.doi.org/10.4049/jimmunol.167.2.935

Hu, D., Duan, Z., Li, M., Jiang, Y., Liu, H., Zheng, H., ... Cao, Y. (2011). Heterogeneity of aberrant immunoglobulin expression in cancer cells. Cellular and Molecular Immunology, 8(6), 479-485. http://dx.doi.org/10.1038/cmi.2011.25

Hu, F., Zhang, L., Zheng, J., Zhao, L., Huang, J., Shao, W., ... Qiu, X. (2012). Spontaneous production of immunoglobulin $\mathrm{M}$ in human epithelial cancer cells. PLoS ONE, 7, pp. e51423. http://dx.doi.org/10.1371/journal.pone.0051423

Huang, J., Sun, X., Mao, Y., Zhu, X., Zhang, P., Zhang, L., ... Qiu, X. (2008). Expression of immunoglobulin gene with classical V-(D)-J rearrangement in mouse brain neurons. International Journal of Biochemistry and Cell Biology, 40(8), 1604-1615. http://dx.doi.org/10.1016/j.biocel.2007.12.004

Huang, J., Zhang, L., Ma, T., Zhang, P., \& Qiu, X. (2009). Expression of immunoglobulin gene with classical 
V-(D)-J rearrangement in mouse testis and epididymisJournal of Histochemistry and Cytochemistry (Vol. 57, pp. 339-349). http://dx.doi.org/10.1369/jhc.2008.951434

Huang, M., Wang, Q., Zhang, W., Li, D., \& Li, L. (2013). [Impact of the biological function on epithelial ovarian cancer with ITIH4 gene expression down-regulating in vitro]. Zhonghua Fu Chan Ke Za Zhi, 48(1), 34-40.

Hurt, E. M., Chan, K., Duhagon Serrat, M. A., Thomas, S. B., Veenstra, T. D., \& Farrar, W. L. (2010). Identification of vitronectin as an extrinsic inducer of cancer stem cell differentiation and tumor formation. Stem Cells, 28(3), 390-398. http://dx.doi.org/10.1002/stem.271

Jozsi, M., \& Zipfel, P. F. (2008). Factor H family proteins and human diseases. Trends Immunol, 29(8), 380-387. http://dx.doi.org/10.1016/j.it.2008.04.008

Junnikkala, S., Jokiranta, T. S., Friese, M. A., Jarva, H., Zipfel, P. F., \& Meri, S. (2000). Exceptional resistance of human $\mathrm{H} 2$ glioblastoma cells to complement-mediated killing by expression and utilization of factor $\mathrm{H}$ and factor H-like protein 1. J Immunol, 164(11), 6075-6081. http://dx.doi.org/10.4049/jimmunol.164.11.6075

Junnikkala, S., Hakulinen, J., Jarva, H., Manuelian, T., Bjorge, L., Butzow, R., ... Meri, S. (2002). Secretion of soluble complement inhibitors factor $\mathrm{H}$ and factor $\mathrm{H}$-like protein (FHL-1) by ovarian tumour cells. British Journal of Cancer, 87(10), 1119-1127.

Kenny, H. A., Kaur, S., Coussens, L. M., \& Lengyel, E. (2008). The initial steps of ovarian cancer cell metastasis are mediated by MMP-2 cleavage of vitronectin and fibronectin. The Journal of Clinical Investigation, 118(4), 1367-1379. http://dx.doi.org/10.1172/jci33775

Kimoto, Y. (1998). Expression of heavy-chain constant region of immunoglobulin and T-cell receptor gene transcripts in human non-hematopoietic tumor cell lines. Genes, Chromosomes and Cancer, 22(1), 83-86. http://dx.doi.org/10.1002/(sici)1098-2264(1998)22:1<83::aid-gcc12>3.0.co;2-o

Kitano, E., \& Kitamura, H. (1993). Synthesis of the third component of complement (C3) by human gastric cancer-derived cell lines. Clinical and Experimental Immunology, 94(2), 273-278.

Krajewska, E., Lewis, C. E., Chen, Y. Y., Welford, A., Tazzyman, S., \& Staton, C. A. (2010). A novel fragment derived from the [beta] chain of human fibrinogen, [beta]43-63, is a potent inhibitor of activated endothelial cells in vitro and in vivo. British Journal of Cancer, 102(3), 594-601.

Laskey, J., Webb, I., Schulman, H. M., \& Ponka, P. (1988). Evidence that transferrin supports cell proliferation by supplying iron for DNA synthesis. Experimental Cell Research, 176(1), 87-95. http://dx.doi.org/http://dx.doi.org/10.1016/0014-4827(88)90123-1

Lee, G., Chen, K.-W., Sheu, F.-S., Tsang, A., Chao, K.-C., \& Ng, H.-T. (1992). Studies of a tumor-associated antigen, COX-1, recognized by a monoclonal antibody. Cancer Immunology, Immunotherapy, 35(1), 19-26. http://dx.doi.org/10.1007/BF01741050

Lee, G., Wu, Q., Li, C. H., Ting, H. H., \& Chien, C.-H. (2006). Recent studies of a new carbohydrate-associated pan cancer marker, CA215Journal of Clinical Ligand Assay (Vol. 29, pp. 47-51)

Lee, G., Laflamme, E., Chien, C.-H., \& Ting, H. H. (2008). Molecular identity of a pan cancer marker, CA215Cancer Biology and Therapy (Vol. 7, pp. 2007-2014). http://dx.doi.org/10.4161/cbt.7.12.6984

Lee, G. (2009). Cancer cell-expressed immunoglobulins: CA215 as a pan cancer marker and its diagnostic applications. Cancer Biomarkers, 5(3), 137-142. http://dx.doi.org/10.3233/cbm-2009-0610

Lee, G., Chu, R.-A., \& Ting, H. H. (2009). Preclinical assessment of anti-cancer drugs by using RP215 monoclonal antibody. Cancer Biology \& Therapy, 8(2), 161-166.

Lee, G., \& Ge, B. (2009). Cancer cell expressions of immunoglobulin heavy chains with unique $\begin{array}{lllll}\text { carbohydrate-associated } & \text { biomarker. } & \text { Cancer } & \text { Biomarkers, } & 5(4),\end{array}$ http://dx.doi.org/10.3233/cbm-2009-0102

Lee, G., Ge, B., Huang, T.-K., Zheng, G., Duan, J., \& Wang, I. H. Y. (2009). Positive identification of CA215 pan cancer biomarker from serum specimens of cancer patients. Cancer Biomarkers, 6, 111-117. http://dx.doi.org/10.3233/cbm-2009-0134

Lee, G., Cheung, A. P., Ge, B., Zhu, M., Li, P. P., Hsu, E., \& Huang, T.-K. (2010). Monoclonal anti-idiotype antibodies against carbohydrate-associate epitope for anti-cancer vaccine development. Journal of Vaccines and Vaccination, 1(2), 1-7. http://dx.doi.org/10.4172/2157-7560.1000106

Lee, G., \& Ge, B. (2010). Inhibition of in vitro tumor cell growth by RP215 monoclonal antibody and antibodies 
raised against its anti-idiotype antibodies. Cancer Immunology, Immunotherapy, 59(9), 1347-1356. http://dx.doi.org/10.1007/s00262-010-0864-7

Lee, G. (2012). Cancerous immunoglobulins and CA215: implications in cancer immunology. American Journal of Immunology, 8(4), 101-116. http://dx.doi.org/10.3844/ajisp.2012.101.116

Lee, G., \& Azadi, P. (2012). Peptide Mapping and Glycoanalysis of Cancer Cell-Expressed Glycoproteins CA215 Recognized by RP215 Monoclonal Antibody. Journal of Carbohydrate Chemistry, 31(1), 10-30. http://dx.doi.org/10.1080/07328303.2011.626544

Lee, G., Cheung, A., Ge, B., Zhu, M., Giolma, B., Li, B., ... Gu, J. (2012). CA215 and GnRH receptor as targets for cancer therapy. Cancer Immunology, Immunotherapy, 1-13. http://dx.doi.org/10.1007/s00262-012-1230-8

Lee, G., Cheung, A. P., Li, B., Ge, B., \& Chow, P.-M. (2012). Molecular and immuno-characteristics of immunoglobulin-like glycoproteins in cancer cell-expressed biomarker, CA215. Immunol Invest, 41(4), 429-446. http://dx.doi.org/10.3109/08820139.2012.661007

Lee, G., \& Ge, B. (2012). Implications of apoptosis in cancer immunotherapy. Advances in Bioscience and Biotechnology, 3, 679-685. http://dx.doi.org/10.4236/abb.2012.326088

Lee, G., Zhu, M., \& Ge, B. (2012). Potential monoclonal antibody therapy for the treatment of ovarian cancer. In Farghaly, S. A. (Ed.), Ovarian Cancer - Basic Science Perspective (pp. 385-406). Vancouver: InTech.

Lee, G., Zhu, M., Ge, B., Cheung, A. P., Chien, C.-H., Chow, S.-N., ... Yao, H.-X. (2012). Carbohydrate-associated immunodominant epitope(s) of CA215Immunological Investigations (Vol. 41, pp. 317-336). http://dx.doi.org/10.3109/08820139.2011.633141

Lee, G., Zhu, M., Ge, B., \& Potzold, S. (2012). Widespread expressions of immunoglobulin superfamily proteins in cancer cells. Cancer Immunology, Immunotherapy, 61(1), 89-99. http://dx.doi.org/10.1007/s00262-011-1088-1

Lee, G., Huang, C.-Y., Liu, S., \& Zhang, H. (2013). The immunology of cancer cells. SOJ Immunology, 1(1), 1-4.

Lee, G., \& Liu, S. (2013). Roles of antigen receptors and CA215 in the innate immunity of cancer cells. Open Journal of Immunology, 3(3), 127-138. http://dx.doi.org/10.4236/oji.2013.33018

Lee, G., Huang, C.-y., \& Ge, B. (2014). Two distinct humanized monoclonal antibodies for immunotherapy of ovarian cancer. Journal of Cancer Science \& Therapy, 6(4), 110-116. http://dx.doi.org/10.4172/1948-5956.1000258

Lee, G., Huang, C.-Y., Tang, Y., \& Zhang, H. (2014). Potential Roles of Cancerous Immunoglobulins in the Immunology of Cancer Cells. Journal of Clinical and Cellular Immunology, 5(2), 1-7. http://dx.doi.org/10.4172/2155-9899.1000200

Lee, G., Huang, C.-Y., Zhang, H., \& Tang, Y. (2014). The Relationships between Toll-like Receptors and RP215-associated Immunoglobulins Expressed by Cancer Cells. Journal of Cancer Science \& Therapy, 6, 77-80. http://dx.doi.org/10.4172/1948-5956.1000252

Li, M., Tang, M., \& Deng, X. (2001). [Positive immunoglobulin A expression in human epithelial carcinoma cell lines]. Zhonghau Zhong Liu Za Zhi, 23(6), 451-453. http://dx.doi.org/CNKI:SUN:ZHZL.0.2001-06-003

Li, M., Feng, D.-y., Ren, W., Zheng, L., Zheng, H., Tang, M., \& Cao, Y. (2004). Expression of immunoglobulin kappa light chain constant region in abnormal human cervical epithelial cells. International Journal of Biochemistry and Cell Biology, 36(11), 2250-2257. http://dx.doi.org/10.1016/j.biocel.2004.03.017

Li, M., Zheng, H., Duan, Z., Liu, H., Hu, D., Bode, A., ... Cao, Y. (2012). Promotion of cell proliferation and inhibition of ADCC by cancerous immunoglobulin expressed in cancer cell lines. Cellular \& Molecular Immunology, 9(1), 54-61. http://dx.doi.org/10.1038/cmi.2011.40

Li, Y., Qu, P., Wu, L., Li, B., Du, H., \& Yan, C. (2011). Api6/AIM/Spa/CD5L overexpression in alveolar type II epithelial cells induces spontaneous lung adenocarcinoma. Cancer Research, 71(16), 5488-5499. http://dx.doi.org/10.1158/0008-5472.can-10-4225

López-Árias, E., Aguilar-Lemarroy, A., Felipe Jave-Suárez, L., Morgan-Villela, G., Mariscal-Ramírez, I., Martínez-Velázquez, M., ... Hernández- Gutiérrez, R. (2012). Alpha 1-antitrypsin: A novel tumor-associated antigen identified in patients with early-stage breast cancer. Electrophoresis, 33(14), 2130-2137. http://dx.doi.org/10.1002/elps.201100491 
Macuks, R., Baidekalna, I., Gritcina, J., Avdejeva, A., \& Donina, S. (2010). Apolipoprotein A1 and transferrin as biomarkers in ovarian cancer diagnostics. Acta Chirurgica Latviensis, 10(2), 16-20. http://dx.doi.org/10.2478/v10163-011-0003-3

Markiewski, M. M., DeAngelis, R. A., Benencia, F., Ricklin-Lichtsteiner, S. K., Koutoulaki, A., Gerard, C., ... Lambris, J. D. (2008). Modulation of the antitumor immune response by complement. Nat Immunol, 9(11), 1225-1235. http://dx.doi.org/10.1038/ni.1655

Markiewski, M. M., \& Lambris, J. D. (2009). Is complement good or bad for cancer patients? A new perspective on an old dilemma. Trends Immunol, 30(6), 286-292. http://dx.doi.org/10.1016/j.it.2009.04.002

Misra, U. K., \& Pizzo, S. V. (2012). Receptor-recognized a2-macroglobulin binds to cell surface-associated GRP78 and activates mTORC1 and mTORC2 signaling in prostate cancer Cells. PLoS ONE, 7(12), e51735. http://dx.doi.org/10.1371/journal.pone.0051735

Nakajima, S., Moriyama, T., Hayashi, H., Sakata, I., Nakae, Y., \& Takemura, T. (2000). Hemopexin as a carrier protein of tumor-localizing Ga-metalloporphyrin-ATN-2. Cancer Letters, 149(1-2), 221-226. http://dx.doi.org/http://dx.doi.org/10.1016/S0304-3835(99)00367-5

Neskey, D., Ambesi, A., Pumiglia, K., \& McKeown-Longo, P. (2008). Endostatin and anastellin inhibit distinct aspects of the angiogenic process. Journal of Experimental and Clinical Cancer Research, 27(1), 61.

Nishimura, H., Kakizaki, I., Muta, T., Sasaki, N., Pu, P. X., Yamashita, T., \& Nagasawa, S. (1995). cDNA and deduced amino acid sequence of human PK-120, a plasma kallikrein-sensitive glycoprotein. FEBS Lett, 357(2), 207-211. http://dx.doi.org/10.1016/0014-5793(94)01364-7

Pasqualini, R., Bourdoulous, S., Koivunen, E., Woods, V. L., Jr., \& Ruoslahti, E. (1996). A polymeric form of fibronectin has antimetastatic effects against multiple tumor types. Nat Med, 2(11), 1197-1203. http://dx.doi.org/10.1038/nm1196-1197

Pineiro, M., Alava, M. A., Gonzalez-Ramon, N., Osada, J., Lasierra, P., Larrad, L., ... Lampreave, F. (1999). ITIH4 serum concentration increases during acute-phase processes in human patients and is up-regulated by interleukin-6 in hepatocarcinoma HepG2 cells. Biochem Biophys Res Commun, 263(1), 224-229. http://dx.doi.org/10.1006/bbrc.1999.1349

Pirazzoli, V., Ferraris, G. M. S., \& Sidenius, N. (2013). Direct evidence of the importance of vitronectin and its interaction with the urokinase receptor in tumor growth. Blood, 121(12), 2316-2323. http://dx.doi.org/10.1182/blood-2012-08-451187

Ponka, P. (1999). Cellular iron metabolism. Kidney Int, 55(S69), S2-S11.

Qiu, X., Zhu, X., Zhang, L., Mao, Y., Zhang, J., Hao, P., ... Zhang, Y. (2003). Human epithelial cancers secrete immunoglobulin $\mathrm{G}$ with unidentified specificity to promote growth and survival of tumor cells. Cancer Research, 63, 6488-6495.

Reis, A., Hennies, H. C., Langbein, L., Digweed, M., Mischke, D., Drechsler, M., ... et al. (1994). Keratin 9 gene mutations in epidermolytic palmoplantar keratoderma (EPPK). Nature Genetics, 6(2), 174-179. http://dx.doi.org/10.1038/ng0294-174

Rossi, M. C., \& Zetter, B. R. (1992). Selective stimulation of prostatic carcinoma cell proliferation by transferrin. Proceedings of the National Academy of Sciences, 89(13), 6197-6201.

Rutkowski, M. J., Sughrue, M. E., Kane, A. J., Mills, S. A., \& Parsa, A. T. (2010). Cancer and the complement cascade. Molecular Cancer Research, 8(11), 1453-1465. http://dx.doi.org/10.1158/1541-7786.mcr-10-0225

Salier, J. P., Rouet, P., Raguenez, G., \& Daveau, M. (1996). The inter-alpha-inhibitor family: from structure to regulation. Biochem J, 315(Pt 1), 1-9.

Schaeffer, E., Boissier, F., Py, M. C., Cohen, G. N., \& Zakin, M. M. (1989). Cell type-specific expression of the human transferrin gene. Role of promoter, negative, and enhancer elements. Journal of Biological Chemistry, 264(13), 7153-7160.

Smorenburg, S. M., Griffini, P., Tiggelman, A., Moorman, A. F., Boers, W., \& Van Noorden, C. J. (1996). $\alpha 2$-Macroglobulin is mainly produced by cancer cells and not by hepatocytes in rats with colon carcinoma metastases in liver. Hepatology, 23(3), 560-570. http://dx.doi.org/10.1002/hep.510230323

Tang, Y., Zhang, H., \& Lee, G. (2013). Similar gene regulation patterns for growth inhibition of cancer cells by RP215 or anti-antigen receptors.Journal of Cancer Science and Therapy (Vol. 5, pp. 200-208). 
http://dx.doi.org/10.4172/1948-5956.1000207

Trowbridge, I. S., \& Lopez, F. (1982). Monoclonal antibody to transferrin receptor blocks transferrin binding and inhibits human tumor cell growth in vitro. Proceedings of the National Academy of Sciences, 79(4), 1175-1179.

Trowbridge, I. S., \& Lopez, F. (1982). Monoclonal antibody to transferrin receptor blocks transferrin binding and inhibits human tumor cell growth in vitro. Proc Natl Acad Sci US A, 79(4), 1175-1179.

Vivanco, I., \& Sawyers, C. L. (2002). The phosphatidylinositol 3-kinase AKT pathway in human cancer. Nat Rev Cancer, 2(7), 489-501. http://dx.doi.org/10.1038/nrc839

Vostrejs, M., Moran, P. L., \& Seligman, P. A. (1988). Transferrin synthesis by small cell lung cancer cells acts as an autocrine regulator of cellular proliferation. The Journal of Clinical Investigation, 82(1), 331-339. http://dx.doi.org/10.1172/JCI113591

Wilczek, E., Rzepko, R., Nowis, D., Legat, M., Golab, J., Glab, M., ... Wilczynski, G. M. (2008). The possible role of factor $\mathrm{H}$ in colon cancer resistance to complement attack. International Journal of Cancer, 122(9), 2030-2037. http://dx.doi.org/10.1002/ijc. 23238

Wu, S. L., Hancock, W. S., Goodrich, G. G., \& Kunitake, S. T. (2003). An approach to the proteomic analysis of a breast cancer cell line (SKBR-3). Proteomics, 3(6), 1037-1046. http://dx.doi.org/10.1002/pmic.200300382

Yi, M., \& Ruoslahti, E. (2001). A fibronectin fragment inhibits tumor growth, angiogenesis, and metastasis. Proceedings of the National Academy of Sciences, 98(2), 620-624. http://dx.doi.org/10.1073/pnas.98.2.620

Yi, W., Peng, J., Zhang, Y., Fu, F., Zou, Q., \& Tang, Y. (2013). [Differential protein expressions in breast cancer between drug sensitive tissues and drug resistant tissues]. Zhong Nan Da Xue Xue Bao Yi Xue Ban, 38(2), 148-154. http://dx.doi.org/10.3969/j.issn.1672-7347.2013.02.007

Yoshimi, K., Woo, M., Son, Y., Baudry, M., \& Thompson, R. F. (2002). IgG-immunostaining in the intact rabbit brain: variable but significant staining of hippocampal and cerebellar neurons with anti-IgG. Brain Research, 956(1), 53-66. http://dx.doi.org/10.1016/s0006-8993(02)03479-0

Zacharski, L. R., Memoli, V. A., \& Rousseau, S. M. (1986). Coagulation-cancer interaction in situ in renal cell carcinoma. Blood, 68(2), 394-399.

Zamanian-Daryoush, M., Lindner, D., Tallant, T. C., Wang, Z., Buffa, J., Klipfell, E., ... Hazen, S. L. (2013). The cardioprotective protein apolipoprotein A1 promotes potent anti-tumorigenic effects. Journal of Biological Chemistry, 288(29), 21237-21252. http://dx.doi.org/10.1074/jbc.M113.468967

Zhang, L., Hu, S., Korteweg, C., Chen, Z., Qiu, Y., Su, M., \& Gu, J. (2012). Expression of immunoglobulin G in esophageal squamous cell carcinomas and its association with tumor grade and Ki67. Human Pathology, 43(3), 423-434. http://dx.doi.org/10.1016/j.humpath.2011.05.020

Zheng, H., Li, M., Liu, H., Ren, W., Hu, D.-s., Shi, Y., ... Cao, Y. (2007). Immunoglobulin alpha heavy chain derived from human epithelial cancer cells promotes the access of $\mathrm{S}$ phase and growth of cancer cellsCell Biology International (Vol. 31, pp. 82-87). http://dx.doi.org/10.1016/j.cellbi.2006.09.009

Zheng, H., Li, M., Ren, W., Zeng, L., Liu, H.-d., Hu, D., ... Cao, Y. (2007). Expression and secretion of immunoglobulin alpha heavy chain with diverse VDJ recombinations by human epithelial cancer cells. Molecular Immunology, 44(9), 2221-2227. http://dx.doi.org/10.1016/j.molimm.2006.11.010

Zheng, J., Huang, J., Mao, Y., Liu, S., Sun, X., Zhu, X., ... Qiu, X. (2009). Immunoglobulin gene transcripts have distinct VHDJH recombination characteristics in human epithelial cancer cellsJournal of Biological Chemistry (Vol. 284, pp. 13610-13619). http://dx.doi.org/10.1074/jbc.M809524200

Zhu, X., Li, C., Sun, X., Mao, Y., Li, G., Liu, X., ... Qiu, X. (2008). Immunoglobulin mRNA and protein expression in human oral epithelial tumor cells. Applied Immunohistochemistry \& Molecular Morphology, 16(3), 232-238. http://dx.doi.org/10.1097/PAI.0b013e31814c915a 


\section{Appendix}

Results of LC-MS/MS analysis of tryptic peptides derived from CA215-S+ and cIgG-S+ (Source: University of Victoria BC Proteomics Center Project \#REC-1434, LC-MS/MS analysis, July 2014)

Table 1. Human serum proteins bound by CA215 (CA215-S+)

\begin{tabular}{|c|c|c|c|c|c|c|c|}
\hline Protein & Probability & $\%$ Spec & \#Pep & \#Unique & \#Spec & $\%$ Cover & Mol. weight \\
\hline Ig kappa chain $\mathrm{C}$ region & $100 \%$ & 0.001467 & 4 & 6 & 16 & $65 \%$ & $12 \mathrm{kDa}$ \\
\hline Ig gamma-1 chain $\mathrm{C}$ region & $100 \%$ & 0.004125 & 6 & 7 & 45 & $57 \%$ & $36 \mathrm{kDa}$ \\
\hline Ig gamma-2 chain $\mathrm{C}$ region & $100 \%$ & 0.004125 & 6 & 9 & 45 & $48 \%$ & $36 \mathrm{kDa}$ \\
\hline Apolipoprotein A-I & $100 \%$ & 0.002109 & 11 & 12 & 23 & $48 \%$ & $31 \mathrm{kDa}$ \\
\hline Haptoglobin & $100 \%$ & 0.00385 & 9 & 12 & 42 & $44 \%$ & $45 \mathrm{kDa}$ \\
\hline Serotransferrin & $100 \%$ & 0.004492 & 22 & 25 & 49 & $38 \%$ & $77 \mathrm{kDa}$ \\
\hline Apolipoprotein D & $100 \%$ & 0.00275 & 7 & 10 & 30 & $38 \%$ & $21 \mathrm{kDa}$ \\
\hline Ig lambda- 2 chain $\mathrm{C}$ regions & $97 \%$ & $2.75 \mathrm{E}-04$ & 1 & 1 & 3 & $32 \%$ & $11 \mathrm{kDa}$ \\
\hline Ig gamma-4 chain $\mathrm{C}$ region & $100 \%$ & 0.001925 & 1 & 1 & 21 & $31 \%$ & $36 \mathrm{kDa}$ \\
\hline $\begin{array}{l}\text { HCG1745306, isoform } \\
\text { CRA_a }\end{array}$ & $100 \%$ & $5.50 \mathrm{E}-04$ & 1 & 1 & 6 & $31 \%$ & $12 \mathrm{kDa}$ \\
\hline Alpha-1-acid glycoprotein 1 & $100 \%$ & 7.33E-04 & 4 & 4 & 8 & $23 \%$ & $24 \mathrm{kDa}$ \\
\hline $\begin{array}{l}\text { Isoform } 2 \text { of Ig mu chain } \mathrm{C} \\
\text { region }\end{array}$ & $100 \%$ & 0.001834 & 9 & 10 & 20 & $23 \%$ & $52 \mathrm{kDa}$ \\
\hline $\begin{array}{l}\text { Isoform } 2 \text { of } \\
\text { Haptoglobin-related protein }\end{array}$ & $100 \%$ & 0.001834 & 1 & 1 & 20 & $22 \%$ & $43 \mathrm{kDa}$ \\
\hline Hemopexin & $100 \%$ & 0.002017 & 7 & 8 & 22 & $19 \%$ & $52 \mathrm{kDa}$ \\
\hline Apolipoprotein M & $100 \%$ & $6.42 \mathrm{E}-04$ & 4 & 4 & 7 & $19 \%$ & $21 \mathrm{kDa}$ \\
\hline Complement C3 & $100 \%$ & 0.004492 & 23 & 24 & 49 & $17 \%$ & $187 \mathrm{kDa}$ \\
\hline Ig alpha- 2 chain $\mathrm{C}$ region & $100 \%$ & 7.33E-04 & 2 & 2 & 8 & $17 \%$ & $37 \mathrm{kDa}$ \\
\hline Fibrinogen beta chain & $100 \%$ & 0.001467 & 6 & 6 & 16 & $16 \%$ & $56 \mathrm{kDa}$ \\
\hline $\begin{array}{l}\text { Immunoglobulin lambda-like } \\
\text { polypeptide } 5\end{array}$ & $71 \%$ & $1.83 \mathrm{E}-04$ & 1 & 1 & 2 & $16 \%$ & $23 \mathrm{kDa}$ \\
\hline $\begin{array}{l}\text { Isoform } 2 \text { of } \\
\text { Alpha-1-antitrypsin }\end{array}$ & $100 \%$ & $5.50 \mathrm{E}-04$ & 4 & 5 & 6 & $15 \%$ & $40 \mathrm{kDa}$ \\
\hline Keratin, type II cytoskeletal 1 & $100 \%$ & $6.42 \mathrm{E}-04$ & 6 & 7 & 7 & $14 \%$ & $66 \mathrm{kDa}$ \\
\hline Alpha-2-macroglobulin & $100 \%$ & 0.004217 & 14 & 17 & 46 & $14 \%$ & $163 \mathrm{kDa}$ \\
\hline Keratin, type I cytoskeletal 9 & $100 \%$ & $6.42 \mathrm{E}-04$ & 4 & 4 & 7 & $14 \%$ & $62 \mathrm{kDa}$ \\
\hline Afamin & $100 \%$ & 0.001467 & 8 & 8 & 16 & $13 \%$ & $69 \mathrm{kDa}$ \\
\hline CD5 antigen-like & $100 \%$ & $6.42 \mathrm{E}-04$ & 3 & 4 & 7 & $12 \%$ & $38 \mathrm{kDa}$ \\
\hline Beta-2-glycoprotein 1 & $100 \%$ & $5.50 \mathrm{E}-04$ & 2 & 2 & 6 & $10 \%$ & $38 \mathrm{kDa}$ \\
\hline Ig alpha-1 chain $\mathrm{C}$ region & $100 \%$ & $5.50 \mathrm{E}-04$ & 1 & 1 & 6 & $9 \%$ & $38 \mathrm{kDa}$ \\
\hline Alpha-1-acid glycoprotein 2 & $100 \%$ & $4.58 \mathrm{E}-04$ & 2 & 2 & 5 & $9 \%$ & $24 \mathrm{kDa}$ \\
\hline Alpha-trypsin chain 2 & $100 \%$ & $2.75 \mathrm{E}-04$ & 2 & 3 & 3 & $9 \%$ & $28 \mathrm{kDa}$ \\
\hline Vitamin D-binding protein & $100 \%$ & $1.83 \mathrm{E}-04$ & 2 & 2 & 2 & $9 \%$ & $55 \mathrm{kDa}$ \\
\hline $\begin{array}{l}\text { C4b-binding protein alpha } \\
\text { chain }\end{array}$ & $100 \%$ & 7.33E-04 & 4 & 4 & 8 & $8 \%$ & $67 \mathrm{kDa}$ \\
\hline Apolipoprotein B-100 & $100 \%$ & 0.005501 & 29 & 29 & 60 & $7 \%$ & $516 \mathrm{kDa}$ \\
\hline
\end{tabular}




\begin{tabular}{|c|c|c|c|c|c|c|c|}
\hline Histidine-rich glycoprotein & $100 \%$ & $3.67 \mathrm{E}-04$ & 3 & 3 & 4 & $7 \%$ & $60 \mathrm{kDa}$ \\
\hline $\begin{array}{l}\text { Isoform Gamma-A of } \\
\text { Fibrinogen gamma chain }\end{array}$ & $100 \%$ & $3.67 \mathrm{E}-04$ & 3 & 3 & 4 & $7 \%$ & $49 \mathrm{kDa}$ \\
\hline Keratin, type I cytoskeletal 10 & $100 \%$ & 0.0011 & 4 & 6 & 12 & $7 \%$ & $59 \mathrm{kDa}$ \\
\hline Keratin, type I cytoskeletal 14 & $100 \%$ & 7.33E-04 & 3 & 3 & 8 & $7 \%$ & $52 \mathrm{kDa}$ \\
\hline $\begin{array}{l}\text { Isoform } 2 \text { of Fibrinogen alpha } \\
\text { chain }\end{array}$ & $100 \%$ & $6.42 \mathrm{E}-04$ & 3 & 3 & 7 & $6 \%$ & $70 \mathrm{kDa}$ \\
\hline $\begin{array}{l}\text { Complement component } \mathrm{C} 4 \mathrm{~B} \\
\text { (Childo blood group) }\end{array}$ & $100 \%$ & 0.001008 & 6 & 6 & 11 & $4 \%$ & $193 \mathrm{kDa}$ \\
\hline $\begin{array}{l}35 \mathrm{kDa} \text { inter-alpha-trypsin } \\
\text { inhibitor heavy chain } \mathrm{H} 4\end{array}$ & $100 \%$ & 3.67E-04 & 4 & 4 & 4 & $4 \%$ & $104 \mathrm{kDa}$ \\
\hline Vitronectin & $87 \%$ & $9.17 \mathrm{E}-05$ & 1 & 1 & 1 & $3 \%$ & $54 \mathrm{kDa}$ \\
\hline $\begin{array}{l}\text { Lipopolysaccharide-binding } \\
\text { protein }\end{array}$ & $98 \%$ & $1.83 \mathrm{E}-04$ & 1 & 1 & 2 & $2 \%$ & $53 \mathrm{kDa}$ \\
\hline Plasminogen & $100 \%$ & $2.75 \mathrm{E}-04$ & 2 & 2 & 3 & $1 \%$ & $91 \mathrm{kDa}$ \\
\hline Complement factor $\mathrm{H}$ & $99 \%$ & $2.75 \mathrm{E}-04$ & 2 & 2 & 3 & $1 \%$ & $139 \mathrm{kDa}$ \\
\hline Anastellin & $72 \%$ & $9.17 \mathrm{E}-05$ & 1 & 1 & 1 & $0 \%$ & $256 \mathrm{kDa}$ \\
\hline
\end{tabular}

Table 2. Human serum proteins bound by $\operatorname{cIgG}(\mathrm{cIgG}-\mathrm{S}+)$

\begin{tabular}{|c|c|c|c|c|c|c|c|}
\hline Protein & Probability & \%Spec & \#Pep & \#Unique & \#Spec & \%Cover & Mol. weight \\
\hline Ig kappa chain $\mathrm{C}$ region & $100 \%$ & 5.36E-04 & 2 & 2 & 9 & $36 \%$ & $12 \mathrm{kDa}$ \\
\hline $\begin{array}{l}\text { Immunoglobulin J chain } \\
\text { (Fragment) }\end{array}$ & $100 \%$ & $2.98 \mathrm{E}-04$ & 2 & 2 & 5 & $27 \%$ & $8 \mathrm{kDa}$ \\
\hline Haptoglobin & $100 \%$ & 0.00137 & 5 & 5 & 23 & $23 \%$ & $45 \mathrm{kDa}$ \\
\hline Ig gamma- 2 chain $C$ region & $100 \%$ & 9.53E-04 & 3 & 4 & 16 & $23 \%$ & $36 \mathrm{kDa}$ \\
\hline $\begin{array}{l}\text { Isoform } 2 \text { of Ig mu chain } \mathrm{C} \\
\text { region }\end{array}$ & $100 \%$ & 0.00143 & 10 & 10 & 24 & $18 \%$ & $52 \mathrm{kDa}$ \\
\hline Alpha-2-macroglobulin & $100 \%$ & 0.002681 & 17 & 20 & 45 & $17 \%$ & $163 \mathrm{kDa}$ \\
\hline $\begin{array}{l}\text { HCG1745306, isoform } \\
\text { CRA_a }\end{array}$ & $99 \%$ & $2.38 \mathrm{E}-04$ & 1 & 1 & 4 & $16 \%$ & $12 \mathrm{kDa}$ \\
\hline Ig gamma-1 chain $\mathrm{C}$ region & $100 \%$ & 8.94E-04 & 2 & 2 & 15 & $16 \%$ & $36 \mathrm{kDa}$ \\
\hline Apolipoprotein A-I & $100 \%$ & $2.38 \mathrm{E}-04$ & 3 & 3 & 4 & $15 \%$ & $31 \mathrm{kDa}$ \\
\hline Ig alpha-1 chain $C$ region & $100 \%$ & 3.57E-04 & 2 & 2 & 6 & $14 \%$ & $38 \mathrm{kDa}$ \\
\hline Ig gamma- 4 chain $C$ region & $69 \%$ & 4.77E-04 & 1 & 1 & 8 & $13 \%$ & $36 \mathrm{kDa}$ \\
\hline $\begin{array}{l}\text { Isoform Gamma-A of } \\
\text { Fibrinogen gamma chain }\end{array}$ & $100 \%$ & 4.77E-04 & 5 & 5 & 8 & $12 \%$ & $49 \mathrm{kDa}$ \\
\hline Ig alpha-2 chain $\mathrm{C}$ region & $100 \%$ & 7.15E-04 & 1 & 1 & 12 & $12 \%$ & $37 \mathrm{kDa}$ \\
\hline $\begin{array}{l}\text { Isoform } 2 \text { of } \\
\text { Haptoglobin-related protein }\end{array}$ & $38 \%$ & $8.34 \mathrm{E}-04$ & 0 & 0 & 14 & $11 \%$ & $43 \mathrm{kDa}$ \\
\hline Serotransferrin & $100 \%$ & $6.55 \mathrm{E}-04$ & 8 & 9 & 11 & $11 \%$ & $77 \mathrm{kDa}$ \\
\hline Keratin, type I cytoskeletal 9 & $100 \%$ & $2.38 \mathrm{E}-04$ & 3 & 3 & 4 & $10 \%$ & $62 \mathrm{kDa}$ \\
\hline Ig lambda-2 chain $\mathrm{C}$ regions & $99 \%$ & $1.19 \mathrm{E}-04$ & 1 & 1 & 2 & $9 \%$ & $11 \mathrm{kDa}$ \\
\hline Fibrinogen beta chain & $100 \%$ & $5.96 \mathrm{E}-04$ & 4 & 4 & 10 & $8 \%$ & $56 \mathrm{kDa}$ \\
\hline Complement $\mathrm{C} 3$ & $100 \%$ & 0.001311 & 12 & 12 & 22 & $8 \%$ & $187 \mathrm{kDa}$ \\
\hline
\end{tabular}




\begin{tabular}{|c|c|c|c|c|c|c|c|}
\hline Keratin, type I cytoskeletal 10 & $100 \%$ & $3.57 \mathrm{E}-04$ & 5 & 5 & 6 & $7 \%$ & $59 \mathrm{kDa}$ \\
\hline Hemopexin & $100 \%$ & 4.77E-04 & 3 & 3 & 8 & $7 \%$ & $52 \mathrm{kDa}$ \\
\hline Vitronectin & $100 \%$ & $1.79 \mathrm{E}-04$ & 2 & 2 & 3 & $6 \%$ & $54 \mathrm{kDa}$ \\
\hline $\begin{array}{l}\text { Lipopolysaccharide-binding } \\
\text { protein }\end{array}$ & $100 \%$ & $3.57 \mathrm{E}-04$ & 2 & 2 & 6 & $5 \%$ & $53 \mathrm{kDa}$ \\
\hline CD5 antigen-like & $92 \%$ & $5.96 \mathrm{E}-05$ & 1 & 1 & 1 & $4 \%$ & $38 \mathrm{kDa}$ \\
\hline $\begin{array}{l}\text { Isoform } 2 \text { of Fibrinogen alpha } \\
\text { chain }\end{array}$ & $100 \%$ & $2.38 \mathrm{E}-04$ & 2 & 2 & 4 & $4 \%$ & $70 \mathrm{kDa}$ \\
\hline Alpha-trypsin chain 2 & $65 \%$ & $5.96 \mathrm{E}-05$ & 1 & 1 & 1 & $4 \%$ & $28 \mathrm{kDa}$ \\
\hline Complement component C9 & $100 \%$ & $1.79 \mathrm{E}-04$ & 2 & 2 & 3 & $4 \%$ & $63 \mathrm{kDa}$ \\
\hline $\begin{array}{l}\text { Immunoglobulin lambda-like } \\
\text { polypeptide } 5\end{array}$ & $93 \%$ & $5.96 \mathrm{E}-05$ & 1 & 1 & 1 & $4 \%$ & $23 \mathrm{kDa}$ \\
\hline Keratin, type II cytoskeletal 1 & $100 \%$ & $1.79 \mathrm{E}-04$ & 3 & 3 & 3 & $4 \%$ & $66 \mathrm{kDa}$ \\
\hline Alpha-1B-glycoprotein & $99 \%$ & $2.98 \mathrm{E}-04$ & 2 & 2 & 5 & $3 \%$ & $54 \mathrm{kDa}$ \\
\hline Gelsolin & $100 \%$ & 7.15E-04 & 3 & 3 & 12 & $3 \%$ & $81 \mathrm{kDa}$ \\
\hline Pregnancy zone protein & $99 \%$ & 4.77E-04 & 1 & 1 & 8 & $3 \%$ & $164 \mathrm{kDa}$ \\
\hline $\begin{array}{l}\text { Isoform } 2 \text { of } \\
\text { Alpha-1-antitrypsin }\end{array}$ & $52 \%$ & $5.96 \mathrm{E}-05$ & 1 & 1 & 1 & $3 \%$ & $40 \mathrm{kDa}$ \\
\hline $\begin{array}{l}\text { C4b-binding protein alpha } \\
\text { chain }\end{array}$ & $87 \%$ & $5.96 \mathrm{E}-05$ & 1 & 1 & 1 & $2 \%$ & $67 \mathrm{kDa}$ \\
\hline Keratin, type I cytoskeletal 14 & $49 \%$ & $5.96 \mathrm{E}-05$ & 1 & 1 & 1 & $2 \%$ & $52 \mathrm{kDa}$ \\
\hline $\begin{array}{l}\text { Inter-alpha-trypsin inhibitor } \\
\text { heavy chain } \mathrm{H} 2\end{array}$ & $100 \%$ & 1.19E-04 & 2 & 2 & 2 & $2 \%$ & $106 \mathrm{kDa}$ \\
\hline $\begin{array}{l}35 \mathrm{kDa} \text { inter-alpha-trypsin } \\
\text { inhibitor heavy chain } \mathrm{H} 4\end{array}$ & $100 \%$ & 1.19E-04 & 2 & 2 & 2 & $2 \%$ & $104 \mathrm{kDa}$ \\
\hline Anastellin & $100 \%$ & $1.79 \mathrm{E}-04$ & 2 & 2 & 3 & $1 \%$ & $256 \mathrm{kDa}$ \\
\hline Complement C5 & $100 \%$ & $2.38 \mathrm{E}-04$ & 2 & 2 & 4 & $1 \%$ & $188 \mathrm{kDa}$ \\
\hline Apolipoprotein B-100 & $100 \%$ & $2.38 \mathrm{E}-04$ & 2 & 2 & 4 & $1 \%$ & $516 \mathrm{kDa}$ \\
\hline Complement factor $\mathrm{H}$ & $84 \%$ & $5.96 \mathrm{E}-05$ & 1 & 1 & 1 & $1 \%$ & $139 \mathrm{kDa}$ \\
\hline $\begin{array}{l}\text { Complement component C4B } \\
\text { (Childo blood group) }\end{array}$ & $54 \%$ & $5.96 \mathrm{E}-05$ & 1 & 1 & 1 & $1 \%$ & $193 \mathrm{kDa}$ \\
\hline
\end{tabular}

Table 3. Human serum proteins bound by CA215 and cIgG

\begin{tabular}{|c|c|c|c|}
\hline \multicolumn{2}{|l|}{$\mathrm{CA} 215(\mathrm{~S}+)$} & \multicolumn{2}{|l|}{$\mathrm{CIG}((\mathrm{S}+)$} \\
\hline Protein & Probability & Protein & Probability \\
\hline $\begin{array}{l}35 \mathrm{kDa} \text { inter-alpha-trypsin inhibitor heavy } \\
\text { chain } \mathrm{H} 4\end{array}$ & $100 \%$ & $\begin{array}{l}35 \mathrm{kDa} \text { inter-alpha-trypsin inhibitor heavy } \\
\text { chain } \mathrm{H} 4\end{array}$ & $100 \%$ \\
\hline Afamin & $100 \%$ & & \\
\hline Alpha-1-acid glycoprotein 1 & $100 \%$ & Alpha-1B-glycoprotein & $99 \%$ \\
\hline Alpha-1-acid glycoprotein 2 & $100 \%$ & & \\
\hline Alpha-2-macroglobulin & $100 \%$ & Alpha-2-macroglobulin & $100 \%$ \\
\hline Alpha-trypsin chain 2 & $100 \%$ & Alpha-trypsin chain 2 & $65 \%$ \\
\hline Anastellin & $72 \%$ & Anastellin & $100 \%$ \\
\hline Apolipoprotein A-I & $100 \%$ & Apolipoprotein A-I & $100 \%$ \\
\hline Apolipoprotein B-100 & $100 \%$ & Apolipoprotein B-100 & $100 \%$ \\
\hline
\end{tabular}




\begin{tabular}{|c|c|c|c|}
\hline Apolipoprotein D & $100 \%$ & & \\
\hline Apolipoprotein M & $100 \%$ & & \\
\hline Beta-2-glycoprotein 1 & $100 \%$ & & \\
\hline C4b-binding protein alpha chain & $100 \%$ & C4b-binding protein alpha chain & $87 \%$ \\
\hline CD5 antigen-like & $100 \%$ & CD5 antigen-like & $92 \%$ \\
\hline \multirow[t]{2}{*}{ Complement $\mathrm{C} 3$} & $100 \%$ & Complement C3 & $100 \%$ \\
\hline & & Complement C5 & $100 \%$ \\
\hline \multirow[t]{2}{*}{$\begin{array}{l}\text { Complement component C4B (Childo blood } \\
\text { group) }\end{array}$} & $100 \%$ & $\begin{array}{l}\text { Complement component } \mathrm{C} 4 \mathrm{~B} \text { (Childo blood } \\
\text { group) }\end{array}$ & $54 \%$ \\
\hline & & Complement component C9 & $100 \%$ \\
\hline Complement factor $\mathrm{H}$ & $99 \%$ & Complement factor $\mathrm{H}$ & $84 \%$ \\
\hline \multirow[t]{2}{*}{ Fibrinogen beta chain } & $100 \%$ & Fibrinogen beta chain & $100 \%$ \\
\hline & & Gelsolin & $100 \%$ \\
\hline Haptoglobin & $100 \%$ & Haptoglobin & $100 \%$ \\
\hline HCG1745306, isoform CRA_a & $100 \%$ & HCG1745306, isoform CRA_a & $99 \%$ \\
\hline Hemopexin & $100 \%$ & Hemopexin & $100 \%$ \\
\hline Histidine-rich glycoprotein & $100 \%$ & & \\
\hline Ig alpha-1 chain $\mathrm{C}$ region & $100 \%$ & Ig alpha-1 chain $\mathrm{C}$ region & $100 \%$ \\
\hline Ig alpha-2 chain $\mathrm{C}$ region & $100 \%$ & Ig alpha-2 chain $C$ region & $100 \%$ \\
\hline Ig gamma-1 chain $\mathrm{C}$ region & $100 \%$ & Ig gamma-1 chain $\mathrm{C}$ region & $100 \%$ \\
\hline Ig gamma-2 chain $\mathrm{C}$ region & $100 \%$ & Ig gamma-2 chain $\mathrm{C}$ region & $100 \%$ \\
\hline Ig gamma-4 chain $\mathrm{C}$ region & $100 \%$ & Ig gamma- 4 chain $\mathrm{C}$ region & $69 \%$ \\
\hline Ig kappa chain $\mathrm{C}$ region & $100 \%$ & Ig kappa chain $\mathrm{C}$ region & $100 \%$ \\
\hline \multirow[t]{2}{*}{ Ig lambda-2 chain $C$ regions } & $97 \%$ & Ig lambda-2 chain $C$ regions & $99 \%$ \\
\hline & & Immunoglobulin J chain (Fragment) & $100 \%$ \\
\hline \multirow[t]{2}{*}{ Immunoglobulin lambda-like polypeptide 5} & $71 \%$ & Immunoglobulin lambda-like polypeptide 5 & $93 \%$ \\
\hline & & Inter-alpha-trypsin inhibitor heavy chain $\mathrm{H} 2$ & $100 \%$ \\
\hline Isoform 2 of Alpha-1-antitrypsin & $100 \%$ & Isoform 2 of Alpha-1-antitrypsin & $52 \%$ \\
\hline Isoform 2 of Fibrinogen alpha chain & $100 \%$ & Isoform 2 of Fibrinogen alpha chain & $100 \%$ \\
\hline Isoform 2 of Haptoglobin-related protein & $100 \%$ & Isoform 2 of Haptoglobin-related protein & $38 \%$ \\
\hline Isoform 2 of Ig mu chain $\mathrm{C}$ region & $100 \%$ & Isoform 2 of Ig mu chain $\mathrm{C}$ region & $100 \%$ \\
\hline $\begin{array}{l}\text { Isoform Gamma-A of Fibrinogen gamma } \\
\text { chain }\end{array}$ & $100 \%$ & $\begin{array}{l}\text { Isoform Gamma-A of Fibrinogen gamma } \\
\text { chain }\end{array}$ & $100 \%$ \\
\hline Keratin, type I cytoskeletal 10 & $100 \%$ & Keratin, type I cytoskeletal 10 & $100 \%$ \\
\hline Keratin, type I cytoskeletal 14 & $100 \%$ & Keratin, type I cytoskeletal 14 & $49 \%$ \\
\hline Keratin, type I cytoskeletal 9 & $100 \%$ & Keratin, type I cytoskeletal 9 & $100 \%$ \\
\hline Keratin, type II cytoskeletal 1 & $100 \%$ & Keratin, type II cytoskeletal 1 & $100 \%$ \\
\hline Lipopolysaccharide-binding protein & $98 \%$ & Lipopolysaccharide-binding protein & $100 \%$ \\
\hline \multirow[t]{2}{*}{ Plasminogen } & $100 \%$ & & \\
\hline & & Pregnancy zone protein & $99 \%$ \\
\hline Serotransferrin & $100 \%$ & Serotransferrin & $100 \%$ \\
\hline Vitamin D-binding protein & $100 \%$ & & \\
\hline Vitronectin & $87 \%$ & Vitronectin & $100 \%$ \\
\hline
\end{tabular}




\section{Copyrights}

Copyright for this article is retained by the author(s), with first publication rights granted to the journal.

This is an open-access article distributed under the terms and conditions of the Creative Commons Attribution license (http://creativecommons.org/licenses/by/3.0/). 